Haciendas and Economic Development 
THIS PAGE INTENTIONALLY LEFT BLANK 
Latin American Monographs, No. 58 Institute of Latin American Studies The University of Texas at Austin 
THIS PAGE INTENTIONALLY LEFT BLANK 


\title{
Haciendas and Economic Development Guadalajara, Mexico, at Independence
}

\author{
by Richard B. Lindley
}

University of Texas Press, Austin 
Library of Congress Cataloging in Publication Data

Lindley, Richard B. (Richard Barry), 1945-

Haciendas and economic development, Guadalajara, Mexico, at independence.

(Latin American monographs; no. 58)

Includes index.

1. Guadalajara Region (Mexico)-Economic conditions.

2. Elite (Social sciences)-Mexico-Guadalajara Region

-History. 3. Haciendas-Mexico-Guadalajara Region-

History. 4. Guadalajara (Mexico)-History. I. Title.

II. Series: Latin American monographs (University of Texas at Austin. Institute of Latin American Studies); no. 58.

HC138.G8L56 $1983 \quad 330.972 ’ 35 \quad 82-17646$

ISBN 0-292-72042-4

Copyright $(\mathcal{C} 1983$ by the University of Texas Press All rights reserved

First Edition, 1983

Requests for permission to reproduce material from this work should be sent to:

Permissions

University of Texas Press

P. O. Box 7819

Austin, Texas 78712 